\title{
Female Entrepreneurship Opportunity: Home-Based Genealogy Business
}

\author{
Mirjana Radović-Marković ${ }^{1}$ \\ Institute of Economic Sciences, Belgrade, Serbia
}

\section{A B S T R A C T}

In the last 15-20 years, the character of genealogical research has transformed gradually. Thus, genealogy is changing into a modern academic discipline. The modern genealogy is supported by digitization of public and genealogical records. At the same time, the new technologies are affecting the development of home-based genealogical research services. The goal of this paper is to offer more ways of encouraging entrepreneurship for genealogists, including the role of the education system and research skills that are especially critical in the field of genealogy and in genealogists' success in their business

KEY WORDS: Entrepreneurship, genealogy, skills, education, home business, communication

\section{Introduction}

The Thinking "entrepreneurially" leads to the intention to start a business and ultimately to the decision to act on that intention (Busenitz and Lau 1996). A new generation of moms is creating a new model for doing business and become very interested in establishing home business. Also, women over 45 age-group is growing rapidly what opened growth potential for the genealogy industry. In this context, the objective of this paper is there-

\footnotetext{
${ }^{1}$ Address: Znaj Jovina 12,11000 Belgrade, e-mail: mirjana.radovic@ien.bg.ac.rs
} 
fore to examine gender of entrepreneur's operation factors on firm performance in the Home-Based Genealogy Business. It provides an understanding of the pre-requisites for female entrepreneurs to succeed in their home businesses, which is of critical importance to survive in the competitive business environment.

\section{Theoretical Overview}

Different theoretical approaches to entrepreneurship show that this field of research is considered as a very broad one. The need to understand entrepreneurial learning and education is critical (Gartner and Birney,2002; Mitchell et al., 2002 and Cope,2005) in order to support acquisition of knowledge and skills required for sustainable business development. Yet, research which examines the "complex interactive learning relationship that exists between the entrepreneur, her/his business and the wider environment" (Cope, 2005) is still in the early stages (Minnitti and Bygrave, 2001; Ravasi and Turati, 2005). Considering the importance of education for entrepreneurs, it has recently become evident that the new Age is looking for new forms of education, such as creative education. Creative education and training should help entrepreneurs to raise their creativity, logical thinking and entrepreneurship skills/capabilities/performance (Radović Marković 2012). Many scientists think that knowledge is probably the most important requirement for business success and therefore it is the factor to which the most attention is being paid. Research in the USA shows that business owners who were not educated enough for the business in which they were engaged were not successful, i.e. more than $80 \%$ of their businesses failed during the first year of its existence (Mirjana Radović Marković 2009). On the contrary, those entrepreneurs who were educated and who showed constant interest for improvement have increased their business success $(60 \%)$ after the completion of basic training programs for entrepreneurship. Certain skills cannot be developed solely by simple multiple-choice exams. New education programs for entrepreneurs must be based on exchanging good practice through studies and networks among strategic partners (researchers, entrepreneurs, financiers, advisors, policy-makers, and so forth). Becoming an entrepreneur, however, is a time-consuming process, and the goal of education is not only to rush students into becoming entrepreneurs, but rather to provide them with tools that enable realistic student self-evaluations even several years after graduation. Extensive literature explores both the role of 
learning in adaptation and strategies for facilitating institutional and social learning in 'complex adaptive systems' (Radovic-Markovic, 2018

There are lot of studies examining the determinants of entrepreneurial activities. their number, size and types. In literature, we can also note that "women entrepreneurs see their businesses more realistically and they make attempts to develop them in family environments, while men gravitate more towards developing a business hierarchy with defined rules and working business procedures" (Radovic-Markovic, 2013, p.4). According to Inmyxai, et a. (2013, p.94), in some cases where males and females have the same types of firm resources," many females are reluctant to transform their economic resources into empowerment outcomes within family because of the threat of social isolation if their husbands should leave them. In addition, "women place significantly less emphasis on making more money through entrepreneurship than they would by working for someone else "(Pruett, at.al. 2018., p.43). It is of particular interest to explore female business background and the organizational characteristics of their enterprises (Avolio and Radovic-Markovic, 2013).

\section{Rules for Running Home Business}

"Today mom-preneurs are very prominent because many women wish to have a family and children, but also have the dream of starting a business" (Radović Marković, 2013 p.131). It is not easy to work from home, although it seems at the first sight. They have a vision of business in home organization, which should provide plenty of time for relaxing, socializing, dealing with family members/affairs and other personal activities. In line with this, they expect that will avoid long business meetings, boss' critics, etc. However, although work from home allows more freedom and different opportunities for quality use of time, still business owners fall into traps, having in mind that they lack organizational capabilities, cannot organize their commitments and time, and sometimes they even lose their identity. In order to succeed in realizing our business intentions and to avoid the traps of running business at home, we shall list several rules which should be followed:

- First, energize your entrepreneurial idea by initiating it and turning it into solid activities. Next, think of how your business will be unique and think of an original way of maximizing the service for clients and customers. In other words, the customers must always 
have your full attention. It is well known that every business is born with a product or a service and that it dies without customers. Therefore, no matter what type of business is started/initiated, whether it is an e-business or a traditional one, it is important to maintain control of all its operations and resources. Among those, customers are considered the greatest source of all. Therefore, connect to your customers and offer them a reason to come back to you. From those reasons, it is very important to create a positive experience for them, which is the combination of everything customers see and in which takes part. Always have in mind that customers' positive experience is a key to success of every small business.

- Emphasize your uniqueness compared to others. Find a market which is does not have a high level and quality of services and offer something new and original. Also, you have to become technical fanatic; use the advantages of the latest technicaltechnological achievements, which should help your business to improve and develop. Permanently innovate and redesign your web presentation and work on it in order to make it more interesting for greater number of visitors and at the same time be connecting with them. Connection to external world over internet is essentially important, as well as connection through professional associations, organizations and similar.

- Need to structure your time; it is necessary to make good time organization in order not to overlap private and business activities and always make work priorities. Try to minimize time you spend outside your office during time dedicated for work.

- Use services of experts and practice team work. Therefore, it is necessary to form a team of experts and external associates that can support or help you if it is necessary for your genealogy research. Monthly meetings with associates are recommended, where all business opportunities, challenges and potential mistakes would be discussed.

- Do not avoid changes. They are sometimes desirable in some segments or elements of your work. In order to initiate them, all circumstances should be considered. Also, associates opinion should be taking into account because they can pay you attention on mistakes, give suggestions and opinions. Therefore, whenever this is 
possible, corrections and changes should be accepted in every project. We can differ two basic types of changes; that is, reactive changes which imply those which are necessary in order to respond to research problems (technical errors, the lack of resources, etc.) and requested changes which imply that these changes may arise from new ideas, new information or new business perspectives. The role of knowledge of entrepreneurs is the most significant; having in mind that management of changes is very risky and sensible process, which demands combination of planning and communication skills, logical and creative capabilities, working experience, etc. These skills are necessary regardless on the type of project and the level the changes are applied

- Manage your project documentation efficiently. Research documentation provides necessary information for research analysis. Therefore, managing documentation is extremely important for that project's success. The basic goals of the management of project documentation are creation of mechanisms of control of project documentation, minimizing errors and securing that all documents are gathered from valuable sources. In order to accomplish these goals, it is necessary to provide appropriate instruments which vary from the simplest to the most complex ones, which are in the basis of every system of project documentation management. System of project documentation management must contain the following elements: that is input which means by which documents will be created. Others are output; that is, determining the way of presentation of documentation which should be distributed (by email, printed material or some other acceptable form), research; that is determining the way of analyzing of gathered documentation (by using specific information of by keywords) and documentation archiving.

Genealogist's responsibility must relate to the following fields of his/her engagement:

- To determine and identify project's and research requirements and accordingly to determine a procedure for gathering project documentation,

- To determine which type of project documentation is needed, considering project plans, contracts, technical documentation, work specification, reports, etc., 
- How and when gathered documentation will be used,

- Who will enter the data in prepared forms,

- How will documentation be applied and used depending on the complexity and the size of project,

- To determine which software will be used,

- To define how will documents be classified by their importance, and

- To determine how the documents will be analyzed.

However, the common thing for all genealogists is the fact that they must define required documentation, to secure its gathering and analyzing, as well as to make it available to clients on time. Managing these activities could be interpreted as having ability, mind and skills which are essential for success. It requires much knowledge, techniques and experience, and above all, their good integration in a whole, which should lead to optimal use of human and financial resources in order to achieve business results.

\section{Key Decisions for Initiate/Start a Home Business}

A Good business plan has to be developed with intention to explore all the defined possibilities for a business. This is maybe the toughest phase of the entrepreneurial process. The integral parts of a typical business plan are:

- Mission

- Overview of key objectives

- The market environment

- Strategy

- Financial forecast

- Activity

Business plan is made at the beginning of each business year and has to be done professionally, which demands hiring managers and entrepreneurs, as well as a number of consultants or specialized agencies in order to take advantage of their potentials. Business plan creation, according to some estimates, needs more than 200 hours of preparations. It has to be made in a way to give a potential investor complete picture and understanding of new business and to enable him to clarify important business components.

An individuals' business plan size is mostly determined based on the amount of resources needed to be invested in planned business. In other 
words, the larger amount of means necessary, the more detailed business plan should be prepared and the more estimates and suggestions should be given. Despite that, realistic average size of business plan is between three to ten pages, which accents the most important business details with related financial estimates.

The activity of creating a formal business plan consumes both time and resources. There are four mechanisms by which a business plan might aid the performance of the venture. When the business plan is prepared, it should be checked once again to evaluate whether the choice of business suits the market, as well as the interest and desires of the future business owner(s). That is, to what extent personal and market interests overlap? At this stage, the most important thing is to balance entrepreneur`s personal goals with market demands.

\section{Part -time or Full- time Home Business}

Many female entrepreneurs start their home business part-time, due to their family commitments and raising children. Others cannot be engaged more than several hours per day, since their home business is considered as an additional or second job, that is, they have other work obligations. Female entrepreneurs usually decide to work from home on a full-time basis when family and financial conditions allow them to do so. In this way, they have maximum dedication to their home business, paying their full attention to it, as well as their time, knowledge and money. However, there are many of those who do not pay any attention to making such a decision, since they do not consider it important. Instead, they expect that they will decide in time, after business inception and depending on the scope of activities how much time they would dedicate to the home-business activities performed every day, so they can choose between two options in time - i.e. to work full or part-time? While making such a decision, one should realistically consider the existing family situation, finance and spare time which allows the entrepreneur to be dedicated to the new enterprise (Mirjana Radović Marković 2009). Sometimes it is very hard to make a clear distinction when the part-time employment becomes the full-time one, having in mind that most of the home-business owners spend most of their spare and work time thinking about their business - about marketing strategies, planning and similar issues. Therefore, it usually happens that the entrepreneur seamlessly 
goes over that boundary, and starts dedicating himself/herself to it full-time, instead of previously part-time engagement.

Most genealogists work part time. According to the U.S. Bureau of Labor Statistics, 57 percent of genealogists are part time while only 34 percent worked full time, as of 1997 (Rada 2011) In other words. Many genealogists are self-employed and work on a contractual basis for their clients. Even though it is a fact that part-time engagement gives more work liberty and provides many personal options. The practice in numerous world-wide countries has shown (the USA and other countries with a long tradition of doing business from home are considered) that engagement of this kind is short-lived, and it rather grows fast to full-time employment. It shows certain advantages, which can be illustrated in the following issues:

- Higher degree of professionalism in business

- Faster development and business progress

- Business market share increase

Despite the advantages, some disadvantages could also be mentioned for full-time engagement. Among the main disadvantages are (Radović Marković and Kyaruzi 2010):

- Greater risk

- Higher initial costs

- Loss of additional job

The aforementioned disadvantages did not significantly contribute to home-business owners discouraging and giving up full dedication to their work. Many of them hold on to the well-known business proverb, "no great risk in business - no great gain". A genealogist's annual earnings may vary considerably depending upon her/his client base, the size of projects to which she/he is assigned. Of all professional genealogists, 50 percent average salaries are between $\$ 22,880$ and $\$ 52,041$ as of January 2011, according to PayScale (Schnotz 2011).

\section{Determination of Success or Failure of a Home Business}

It is logical to expect that everyone who starts a new business wishes that it succeeds, regardless of the type of business and the way it is organized and ran. But, what does it mean to be successful in business? As an entrepreneur, this is a question which you are expected to ask yourself, having in mind that you spend your energy, time and money, as well as talent to 
create a new business. Despite all efforts, experience and knowledge sometimes it may seem that business is not going the way you want and as you expected. Therefore, self-evaluations important as it should be a part of your daily management process. Learning "how you work" may be an excellent basis for deciding which way to take next. There are several tests which can help in determining how good or bad is your business. One must have in mind that the success of a five-year lasting business cannot be evaluated in the same way as the one that is lasting only for six months, which is practically in the phase of development/incubation.

Some of these ways for determining the road on which the business is are:

(a) Have you achieved all planned goals? Compare your business plan with your results. Also compare performances of your business to competition businesses. Determine your part of the market,

(b) Do you pay your bills regularly? One of the main indicators of your business' successfulness is whether you are in a position to cover your expenses on time and to pay your duties and taxes. If you are, you may consider your business as good functioning one. If you are not able to fulfill these commitments, then it is necessary to make certain steps and to make additional efforts to improve your business activities. Maybe the only thing you have to do is to decrease your expenses or maybe your choice of business was wrong. Also, do not expect that you can make so much money in the phase of development that you can fulfill your desires, because of which you founded the business. The advice for all those who enter entrepreneurial waters is to be patient and to do their work well and qualitative. If you work in this manner, in long-terms your business will certainly fulfill your material and other expectations,

(c) Have you done more as an entrepreneur or when you were employed at someone else's? Many entrepreneurs start their own business because they are not satisfied with their current job, material and social status. Therefore, when you enter entrepreneurial waters, it is necessary to ask yourself do you earn now more compared to period when you were working for someone else. Also, it is desirable to compare earnings of your colleagues which run similar businesses, have similar education and working experience as an entrepreneur similar to yours. All these answers will be an excellent index to show you whether you are more successful now than in the previous job when you were employed by someone else. Not only the evaluation of your success, but also the making of a decision what to change 
in professional plan in the future, that is, whether the existing business should be modified in some segments or replaced with some other, will depend on those answers,

(d) What does a financial report show? A simple financial ratio analysis is the best way to show financial weaknesses and advantages of your business,

(e) How are the sales doing? It is necessary to examine the trend of the sales of your products by comparing the data with previous month and previous year. If you notice a constant decrease of your sales, you must stop and make a different sales strategy. Actually, these data should show whether your marketing efforts are efficient, do the distribution mechanisms operate well and is there still an expressed demand for your products or services,

(f) Do you make profit? Do you lose or earn money? When can you expect profit from your business? Do you have sufficient financial means to cover expenses and losses while your business is without profit? In long terms, is your business profitable at all?

(g) How do you feel about your business? Maybe the answer to this question is one of the best indexes whether you have achieved business success or not. Actually, many entrepreneurs start their business from different motives. Some of them were already mentioned, but the one which is of extreme importance is whether the business is approached with the same passion as in the beginning?

At the end of this analysis you may conclude whether your business is worth your engagement and effort. But, only the business which fulfills you in every way and makes you happy can bring you success.

\section{Turning Genealogy Hobby into Home-based Business}

A Bank of America analysis reported "Nine million internet users describe genealogy as a "core passion/hobby", and the majority of these (7.5 million) are 45 years and older (US census,2011). According to Archives.com, about $65 \%$ of members are female and only $35 \%$ are male. A Harris Interactive survey estimated that $87 \%$ of American adults are interested in learning about their family histories (http://corporate.ancestry.com). Despite the genealogy is being considered as a hobby, there are many opportunities for encouraging entrepreneurship for genealogists. The advantages to run this business are that we can start it with a minimum investment $(\$ 2,000$ - $\$ 10,000)$, do it part time and from home. 
Businesses that genealogists and other entrepreneurs do in their homes are relatively new. According to many indexes, these businesses are very stable, which is affirmed by data which show that the average age of businesses which owners run from their homes is around six years (RadovicMarkovic 2009). The research also showed that workers who work at home use computers and modern technologies more than in other types of businesses in order to do their everyday tasks. In this way, by opening the door to modern technology and by using it in every day work situations, they gained more opportunities in choosing businesses which best suit their life style and made running a business much easier (Mirjana Radović Marković 2010).

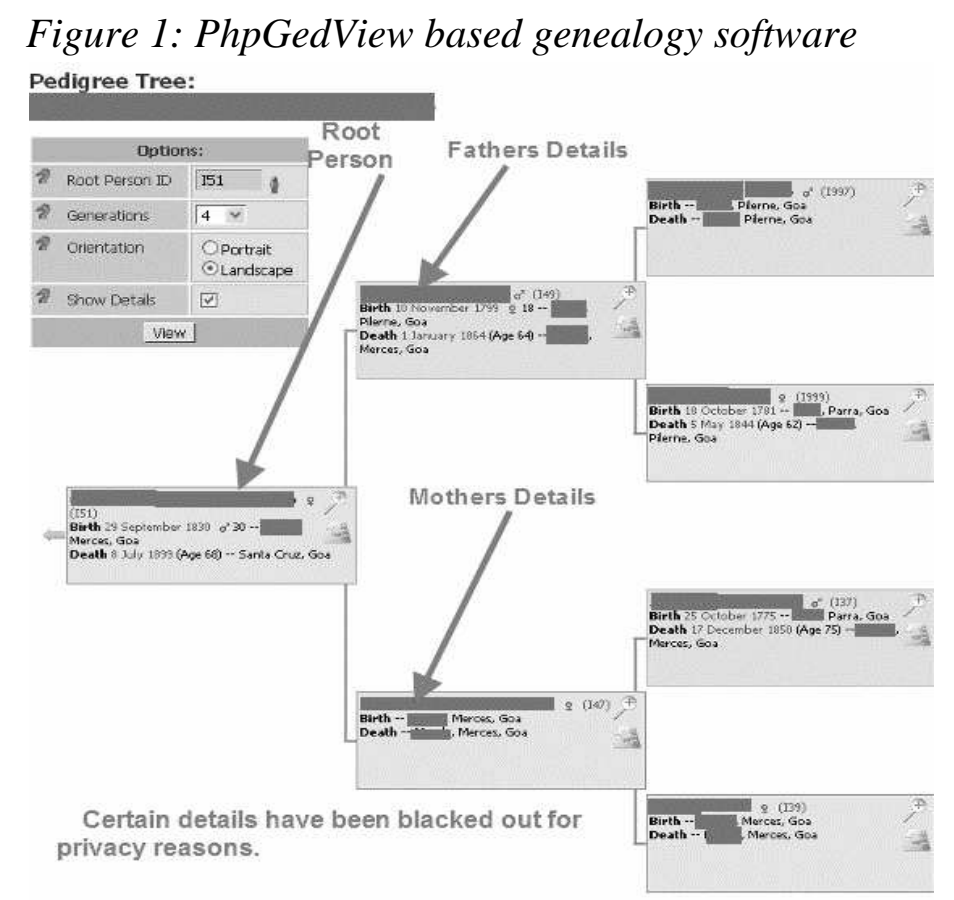

Source: https://www.infosolutionsgoa.com/deployment/phpgedview-genealogysoftware.html

The internet plays a huge role in a genealogy business because it is a great source of information. Internet services, in conjunction with the existing and more widely used communication media, provide the broadest enhancement of information and communication resources. In line with this, "genealogy business could become a mixture of researching jobs for clients, 
consultation for professionals and speaking engagements for groups and conventions geared to family history research plus freelance writing on the subject for websites, blogs, magazines and other reference sources" (Wallin, 2018). Namely, today genealogists have given rise to the capabilities that make it remarkably easy for many people with a casual interest in genealogy to quickly assemble an accurate view of their family history (Voelker 2011). Thanks to some new software, it s very easy to create and manage tasks. So, PhpGedView is one of the leading PHP based genealogy software (Fig.1).

Lots of genealogists are still working toward combining their hobbies into their career. The genealogist business is varied, and an entrepreneur can choose the genealogist business according to his/her specialty - in order to design and run genealogical websites, research family history or to conduct family history consultations.

\section{Conclusion}

The new economy is very often erroneously related to internet concept. However, this economy relies on the need of good informing and applying the best international modern entrepreneurial experiences. Therefore, small businesses owners now face a permanent task to gain knowledge and continual examination of competition all around the world. Besides that, they have to accept the fact that they can make business formula of success which should find market, meet customers' demands and offer/render services at the lowest prices possible. Networking is a huge part of any successful entrepreneurial endeavor. Research skills and professionalism are critical in the field of genealogy. In other words, success of home-based firms depends primarily on the genealogist research competency, much more than on the technological competencies. Namely, their research is actually a voyage of discovery and their business innovation.

Finally, many recent trends have positively impacted the genealogy industry. At the same time, internet penetration and usage will disrupt existing business models and make way for new ones. Namely, consider just lot of the ongoing and upcoming digitization projects that will offer historical records, many at no cost to the user will make an impact on genealogy popularity. In line with this, we hope that this challenge will stimulate more research in this field, as well as, help genealogists to turn their nice dreams into a successful and profitable business. 


\section{References}

[1] Archive.com: Online Family History Trends, February, 2012 http://www.archives.com/blog/miscellaneous/online-family-history-trends1.html\#_ednref9

[2] Avolio, Beatrice and Radović Marković, Mirjana. (2013). Women and Entrepreneurship Female Durability, Persistence and Intuition at Work Women and Entrepreneurship, Gower, UK

[3] Busenitz, W. Lowell and Lau, Chung-Ming. 1996. "A cross-cultural cognitive model of new venture creation". Entrepreneurship Theory and Practice 20(4):25-39

[4] Compete.com: Findagrave.com, Familysearch.org, Rootsweb.com, USGWArchives.net, Cyndislist.com, USgenweb.org. Accessible from: http://www.compete.com/.

[5] Cope, Jason.2005. Toward a dynamic learning perspective of entrepreneurship. Entrepreneurship Theory and Practice 29 (4): 373-97.

[6] Harris Interactive, July 2009. Accessible from: http://corporate.ancestry.com/library/media/Getting\%20Started\%20OneSheet\%202.19.10.pdf.

[7] Gartner, B. William and Birney, Sue .2002. "Introduction to the special issue on qualitative methods in entrepreneurship research". Journal of Business Venturing, 17, 387-395.

[8] Inmyxai, Sengaloun, Takahashi Yoshi, and Nham Phon. 2013. Gender as a Moderator, Journal of Women's Entrepreneurship and Education, 2013, No. 1-2, 90-114.

[9] Mitchell, Ron et.al. 2002. "Toward a theory of entrepreneurial cognition: Rethinking the people side of entrepreneurship research". Entrepreneurship Theory and Practice, 27 (2), 93-104.

[10] Minniti, Maria and Bygrave, William. 2001. "A dynamic model of entrepreneurial learning". Entrepreneurship: Theory and Practice 23 (4): 41-52.

[11] Pruett, Mark, Şeşen, Harun, Pandian, Rajendran and Winter, Greg, 2018. Female Students: Afghanistan's New Entrepreneurs? Journal of Women's Entrepreneurship and Education, 2018, No. 1-2, 40-5

[12] Rada, James. 2011. "How Much Does a Genealogist Make?" Accessible from: http://www.ehow.com/info_7942342_much-genealogistmake.html\#ixzz1ljOzOLG4

[13] Radović-Marković, Mirjana and Silver Imani Kyaruzi. 2010. Women in Business: Theory, Practice and Flexibile Approach, Adonis and Abbey. Ltd., London, pages 162.

[14] Radović-Marković, Mirjana. 2009. Women Entrepreneurs: New opportunities and Challenges, Indo-American Books, Delhi, India, p. 206 
[15] Radović Marković, Mirjana. 2012. Impact of Globalization on Organizational Culture, Behaviour and Gender Role, IAP, Charlotte, NC, SAD ,148 p.

[16] Radović Marković, Mirjana 2013. Female Entrepreneurship: Theoretical Approaches, Journal of Women's Entrepreneurship and Education, 2013, No. 1-2, pp. 1-9.

[17] Radović Marković, Mirjana. 2018. Organizational resilience and business continuity: Theoretical and conceptual framework, Journal of Entrepreneurship and Business Resilience, 2018, Year I, number 1, pp. 5-11

[18] Ravasi, Davide and Turati, Chiara.2005. Exploring entrepreneurial learning: A comparative study of technology development projects, Journal of Business Venturing

[19] Schnotz, William. 2011. Professional Genealogist Salary http://www.ehow.com/info_7805586_professional-genealogist-salary.html

[20] U.S. Census Bureau,2011. "Population Profile of the United States: The Elderly Population," Author Frank B. Hobbs, http://www.census.gov/.

[21] Voelker, Dave. 2011. Serial Entrepreneurship and Genealogy, Genealogy Industry http://www.digicopia.com/serial-entrepreneurship-genealogy/

[22] Wallin, C. 2018. A Genealogy Business Is About Family. Avaiable at: https://extraincomeover55.com/genealogy-business-family/

[23] Wickham, Phillip .2001. Strategic Entrepreneurship: A Decision-Making Approach to New Venture Creation and Management, Financial Times Management

Article history: $\quad$ Received: 7 November, 2018

Accepted: 3 December, 2018 